\title{
Development of a Suitable Heat Exchanger Temperature Controller for a Typical Milk Pasteurization Process
}

\author{
Ismaila Adeniyi Kamil \\ Department of Electrical \& Electronic Engineering, University of Ibadan, Nigeria \\ niyikamil@yahoo.com
}

\begin{abstract}
High Temperature Short Time (HTST) pasteurization is the conventional method used in the food industry in producing edible milk. This process requires that a control system be put in place to regulate the heating temperature of the milk during production. Most local milk processing factories have not been deploying appropriate controllers for this process. This work aimed at designing suitable controller for an optimum HTST milk pasteurization process using a local milk processing factory as a case study. In this paper, the dynamic behavior of a plate heat exchanger (PHE) is modelled using equivalent electric circuit parameter modeling of thermal systems. The resulting transfer function demonstrates how changes in steam flow rate and milk inflow temperature (disturbance) affect the milk output temperature. Through simulation in MATLAB environment, the process time responses to both set point and disturbance inputs are obtained in open loop mode and by using three forms of Proportional, Integral and Derivative (PID) controllers in a unit feedback mode. A feedforward controller is also added for pre-emptive control. The results obtained show that the combination of the Feedforward and Proportional plus Derivative (PD) controllers is the most suitable for this process as it maintains a balance between speed of response, stability margin and disturbance rejection.
\end{abstract}

Keywords: Milk pasteurization; Plate heat exchanger; PID controller; Feedforward controller

\section{Introduction}

Naturally milk, as secreted by the udder cells of a healthy cow, is hygienic. That is, it contains no micro-organisms that are capable of decomposing the milk constituents or causing disease to the consumers of the milk. However, as it comes in contact with cow dung, infected skin and udders of cows or dirty equipment, the milk is rendered unhygienic because of the presence of disease-causing bacteria [1]. Pasteurization is thus the process of using heat treatment to kill most (over 99\%) of the harmful bacteria and other microorganisms present in the milk [2,3]. The process is named after the French scientist Louis Pasteur. It was developed after his work on souring of wine and beer had shown that heating them to a temperature of about $54.4^{\circ} \mathrm{C}\left(131^{\circ} \mathrm{F}\right)$ for a short time delayed souring.

Among many pasteurization methods, the High Temperature Short Time (HTST) method is usually accepted as the industry standard [4]. Pasteurization heat treatment is markedly used to disinfect milk without much damage to its chemical structure. This is because the heat is applied at considerably high temperature over short time, so called High Temperature Short Time Pasteurization (HTST).

A control system is required in heating milk to an appropriate temperature without the risk of damaging the milk's physical and chemical properties due to overheating. Yet, the control of production process in the food industry has always focused on examination of end products, since feedback of test results to the production process is generally not

Received (April 4, 2018), Review Result (June 4, 2018), Accepted (June 19, 2018) 
possible as it takes too long before the results of the analyses are known [5]. Therefore, analysis at the end of the process has shifted to control of the process by introduction of good manufacturing practice (GMP) and hazard appraisal (analysis) critical control points (HACCP) systems. The use of a continuous, preferably in-line, monitoring system is necessary to make sure that the critical points in the process are controlled. This enables rapid detection and correction of slight deviations of process parameters yielding increased productivity and profitability. In addition, large margins that are used in the heat treatments, to prevent safety issues, can be minimized to improve quality aspects such as nutritional value and taste.

These reasons necessitate the design of a temperature control system that will ensure that milk pasteurization is carried out optimally and respond more rapidly and accurately than human intervention. The PID algorithm is the most popular feedback controller used within the process industries as it has been successfully used for over 50 years $[6,7]$. It is a robust and easily understood algorithm that can provide excellent control performance despite the varied dynamic characteristics of a process plant.

Plate Heat Exchanger (PHE) is a device that is used to transfer thermal energy between two fluid streams at different temperatures without mixing the two streams. It is employed in milk pasteurization plant and is designed such that heat can be indirectly transferred to the milk to heat it up to the desired temperature. The flow pattern of the Plate Heat Exchanger as shown in Figure 1 is such that the milk to be heated flows in a counter current direction [8] with the one that will be cooled. This has the advantage of saving energy in the process plant, as extra heating is not needed in warming up before pasteurization [9] and cooling devices are also unnecessary in cooling down the milk before chilling.

In this work, an appropriate heat exchange controller is developed for milk pasteurization in a local milk factory. In developing the system model, the parameters of a local milk factory are used. In this way, the developed controller is suitable for the factory operation but can be adapted to other application areas.

\section{System Modelling}

The mathematical model for the plate heat exchanger is first developed. The following assumptions were made in realizing the PHE model used for this work:

(i) All physical properties for incoming fluid flows are known.

(ii) Heat exchanger is insulated from its surroundings, in which case the only heat exchange is between hot and cold fluids (an adiabatic thermal system).

(iii) Conduction losses along the walls are negligible

(iv) Fluid is flowing only in one direction inside each heat exchanger channel.

(v) All fluids enter the heat exchanger with a uniform velocity.

(vi) Overall heat transfer coefficient changes over the heat surfaces are negligible.

With these assumptions, the constitutive relations for the plate heat exchanger is modeled by analyzing the thermal system as being analogous to electrical systems so that they can contain both resistive and capacitive elements [10]. Using circuit analyses, the model becomes easy to analyze as coupled differential equations and solve into plant transfer function. Table 1 shows the analogy between various elements of a thermal system and those of an electrical circuit. 


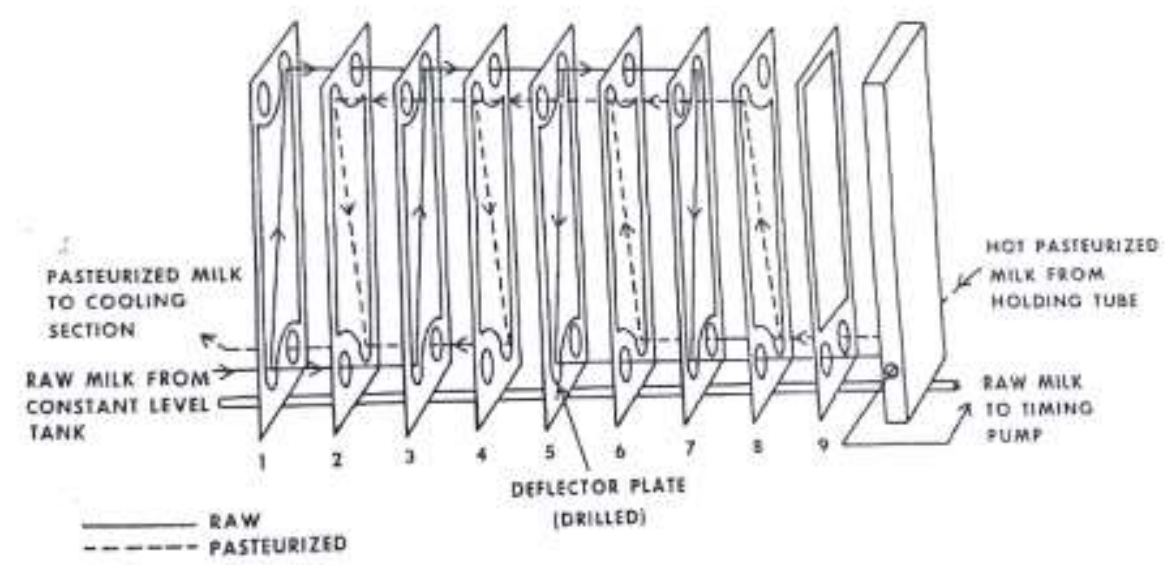

Figure 1. The Flow Pattern in a Plate Heat Exchanger

Table 1. Equivalent Electric Circuit Parameters of Thermal Elements

\begin{tabular}{|l|c|c|c|}
\hline \multicolumn{1}{|c|}{ Thermal Parameter } & $\begin{array}{c}\text { Symbol/ } \\
\text { Unit }\end{array}$ & $\begin{array}{c}\text { Equivalent Electric Circuit } \\
\text { Parameter }\end{array}$ & $\begin{array}{c}\text { Symbol/ } \\
\text { Unit }\end{array}$ \\
\hline Fluid Flow Rate & $\mathrm{G}(\mathrm{kg} / \mathrm{s})$ & Current & $\mathrm{I}(\mathrm{A})$ \\
\hline Temperature & $\mathrm{T}(\mathrm{K})$ & Voltage & $\mathrm{V}(\mathrm{V})$ \\
\hline Fluid Convective Resistance & $\mathrm{R}(\mathrm{K} / \mathrm{W})$ & Resistance & $\mathrm{R}(\Omega)$ \\
\hline Plate Conductive Resistance & $\mathrm{R}(\mathrm{K} / \mathrm{W})$ & Resistance & $\mathrm{R}(\Omega)$ \\
\hline
\end{tabular}

Based on this concept, the thermal system is modelled in its electric circuit analogy as shown in Figure 2 where:

$\mathrm{R}_{\mathrm{M}}=$ Milk convective resistance

$\mathrm{G}_{\mathrm{M}}=$ Milk flow rate inside the PHE

$\mathrm{T}_{\mathrm{M}}=$ Milk temperature, flowing into the PHE

$\mathrm{T}_{\mathrm{M}}{ }^{\prime}=$ Milk temperature inside the PHE

$\mathrm{T}_{\alpha}=$ Ambient temperature

$\mathrm{C}_{\mathrm{M}}=$ Milk thermal capacitance

$\mathrm{C}_{\mathrm{PM}}=$ Milk specific heat capacity

$\mathrm{R}_{\mathrm{SW}}=$ Steam to wall thermal resistance
$\mathrm{T}_{\mathrm{S}}=$ Steam temperature into the PHE

$\mathrm{T}_{\mathrm{S}}{ }^{\prime}=$ Steam temperature inside the PHE

$\mathrm{G}_{\mathrm{S}}=$ Steam flow rate in the PHE

$\mathrm{C}_{\mathrm{PS}}=$ Steam specific heat capacity

$\mathrm{R}_{\mathrm{S}}=$ Steam convective resistance

$\mathrm{C}_{\mathrm{S}}=$ Steam thermal capacitance

$\mathrm{T}_{\mathrm{W}}=$ PHE temperature

$\mathrm{R}_{\mathrm{MW}}=$ Milk to wall thermal resistance

In order to develop a mathematical model for the thermal system from the equivalent circuit in Figure 2, the concept of energy balance is used.

Thus, the heat delivered by the steam, the heat transferred through the wall of the heat exchanger and the heat stored in the milk were used to model the PHE.

Letting $R_{S W}$ and $R_{M W}$ be defined as in equations (1) and (2), the heat distribution on the steam side is given by equation (3) 


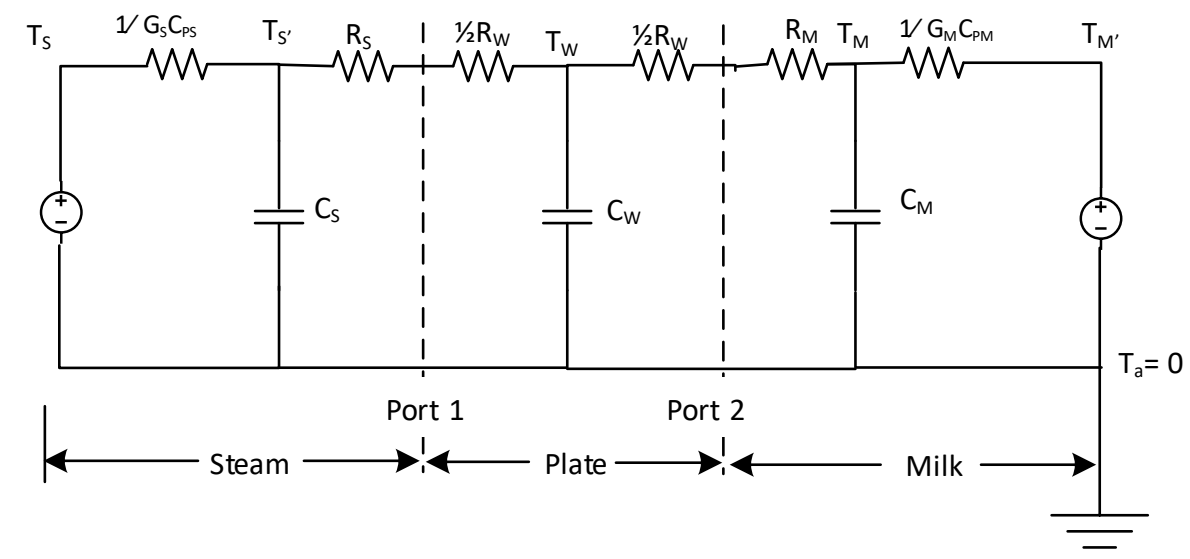

Figure 2. Lumped Parameter Circuit Model of the Plate Exchanger

$$
\begin{aligned}
& R_{S W}=R_{S}+\frac{1}{2} R_{W} \\
& R_{M w}=R_{M}+\frac{1}{2} R_{W} \\
& G_{S} C_{P S}\left(T_{S}-T s^{\prime}\right)=\frac{T s^{\prime}-T_{W}}{R_{S W}}+C_{S} \frac{d T s^{\prime}}{d t}
\end{aligned}
$$

Steam is the most common heating medium which in conducting transfers its latent heat to flow of heat stream causing heat load to be proportional to steam flow [11]. Therefore, equation (3) can be rewritten as:

$$
G_{S} H_{S}=\frac{\left(T s^{\prime}-T_{W}\right)}{R_{S W}}+C_{S} \frac{d T s^{\prime}}{d t}
$$

where $\mathrm{H}_{\mathrm{S}}$ is the latent heat of steam.

The heat transferred through wall of plate heat exchanger is modeled thus:

$\frac{\left(T s^{\prime}-T_{W}\right)}{R_{S W}}=\frac{\left(T_{W}-T m^{\prime}\right)}{R_{M W}}+C_{W} \frac{d T w}{d t}$

The heat distribution of the milk side, from Figure 2 circuit model is given by:

$G_{M} C_{P M}\left(T_{M}-T_{M}^{\prime}\right)+\frac{\left(T_{W}-T_{M}^{\prime}\right)}{R_{M W}}=C_{M} \frac{d T_{M}^{\prime}}{d t}$

For heat to be absorbed, the temperature of the milk must be lower than the supplied steam, and in this case no heat is transferred from the milk to the steam [12].

The variables in the three coupled differential equations are; $\mathrm{G}_{\mathrm{S}}, \mathrm{T}_{\mathrm{S}}{ }^{\prime}, \mathrm{T}_{\mathrm{W}}, \mathrm{T}_{\mathrm{M}}$ ' and $\mathrm{T}_{\mathrm{M}}$. The values of the constants $\mathrm{H}_{\mathrm{S}}, \mathrm{R}_{\mathrm{SW}}, \mathrm{C}_{\mathrm{S}}, \mathrm{R}_{\mathrm{WM}}, \mathrm{G}_{\mathrm{M}}, \mathrm{C}_{\mathrm{PM}}$ and $\mathrm{C}_{\mathrm{W}}$ are obtained from the plant process unit parameters.

The differential equations (4), (5) and (6) will be solved in order to obtain a single transfer function that models the entire system. In doing this, other variables are eliminated except $G_{S}$ and $T_{S}$ ' which determine the dynamic response of how steam raises the milk pasteurization temperature. 
By eliminating $T_{W}$ and $T s^{\prime}$ using equations (4), (5) and (6) a $3^{\text {rd }}$ order differential equation which is a function of $G_{S}, T_{M}$ and $T_{M}$ is obtained as:

$$
\begin{aligned}
& G_{S} H_{S}=-G_{M} C_{S} C_{W} C_{P M} R_{S W} R_{W M} \frac{d^{2} T_{M}}{d t^{2}}-\left[G_{M} C_{W} C_{P M} R_{W M}+G_{M} C_{S} C_{P M} R_{W M}+\right. \\
& \left.G_{M} C_{S} C_{P M} R_{S W}+\frac{C_{M} R_{M W}}{R_{S W}}\right] \frac{d T_{M}}{d t}-G_{M} C_{P M} T_{M}+C_{S} C_{W} C_{M} R_{S W} R_{W M} \frac{d^{3} T_{M}^{\prime}}{d t^{3}}\left[C_{W} C_{M} R_{W M}+\right. \\
& \left.C_{S} C_{M} R_{W M}+G_{M} C_{S} C_{W} C_{P M} R_{S W} R_{W M}+C_{S} C_{W} R_{S W}+C_{S} C_{M} R_{S W}\right] \frac{d^{2} T_{M^{\prime}}}{d t^{2}}+ \\
& {\left[G_{M} C_{W} C_{P M} R_{W M}+C_{W}+C_{M}+G_{M} C_{S} C_{P M} R_{W M}+C_{S}+G_{M} C_{S} C_{P M} R_{S W}+\right.} \\
& \left.\frac{C_{M} R_{M W}}{R_{S W}}\right] \frac{d T_{M}{ }^{\prime}}{d t}+G_{M} C_{P M} T_{M}{ }^{\prime}
\end{aligned}
$$

Since the controlled variable is the milk temperature $T_{M}^{\prime}$, in the plate heat exchanger which is the output temperature of the milk that is measured, the equation can be rearranged by collecting the terms involving the output milk temperature $T_{M}$ ' on the right-hand side (RHS). The $G_{S}$ and $T_{M}$ terms are collected on the left-hand side (LHS) of the equation as follows:

$$
\begin{aligned}
& \text { LHS }=G_{S} H_{S}+G_{M} C_{S} C_{W} C_{P M} R_{S W} R_{W M} \frac{d^{2} T_{M}}{d t^{2}}+\left[G_{M} C_{W} C_{P M} R_{W M}+G_{M} C_{S} C_{P M} R_{W M}+\right. \\
& \left.G_{M} C_{S} C_{P M} R_{S W}+\frac{C_{M} R_{M W}}{R_{S W}}\right] \frac{d T_{M}}{d t}-G_{M} C_{P M} T_{M} \\
& \text { RHS }=C_{S} C_{W} C_{M} R_{S W} R_{W M} \frac{d^{3} T_{M}{ }^{\prime}}{d t^{3}}\left[C_{W} C_{M} R_{W M}+C_{S} C_{M} R_{W M}+G_{M} C_{S} C_{W} C_{P M} R_{S W} R_{W M}+\right. \\
& \left.C_{S} C_{W} R_{S W}+C_{S} C_{M} R_{S W}\right] \frac{d^{2} T_{M^{\prime}}}{d t^{2}}+\left[G_{M} C_{W} C_{P M} R_{W M}+C_{W}+C_{M}+G_{M} C_{S} C_{P M} R_{W M}+C_{S}+\right. \\
& \left.G_{M} C_{S} C_{P M} R_{S W}+\frac{C_{M} R_{M W}}{R_{S W}}\right] \frac{d T_{M}}{d t}+G_{M} C_{P M} T_{M^{\prime}}
\end{aligned}
$$

Taking the Laplace transforms of (8a) and (8b),

$$
\begin{aligned}
& \mathrm{LHS}=G_{S} H_{S}(s)+G_{M} C_{S} C_{W} C_{P M} R_{S W} R_{W M} s^{2} T_{M}(s)+\left[G_{M} C_{W} C_{P M} R_{W M}+\right. \\
& \left.G_{M} C_{S} C_{P M} R_{W M}+G_{M} C_{S} C_{P M} R_{S W}+\frac{C_{M} R_{M W}}{R_{S W}}\right] s T_{M}(s)-G_{M} C_{P M} T_{M}(s) \\
& \mathrm{RHS}=C_{S} C_{W} C_{M} R_{S W} R_{W M} s^{3} T_{M}^{\prime}(s)\left[C_{W} C_{M} R_{W M}+C_{S} C_{M} R_{W M}+\right. \\
& \left.G_{M} C_{S} C_{W} C_{P M} R_{S W} R_{W M}+C_{S} C_{W} R_{S W}+C_{S} C_{M} R_{S W}\right] s^{2} T_{M}{ }^{\prime}(s)+\left[G_{M} C_{W} C_{P M} R_{W M}+C_{W}+\right. \\
& \left.C_{M}+G_{M} C_{S} C_{P M} R_{W M}+C_{S}+G_{M} C_{S} C_{P M} R_{S W}+\frac{C_{M} R_{M W}}{R_{S W}}\right] s T_{M}^{\prime}(s)+G_{M} C_{P M} T_{M}^{\prime}(s)
\end{aligned}
$$

Equations (9a) and (9b) suggest that there are two inputs into the system - $G_{S}(s)$ which is the steam flow rate into the PHE and $T_{M}(s)$, the input milk temperature disturbance into the system. Therefore, the response due to each input is obtained by equating the other input to zero in $9 \mathrm{a}$ and $9 \mathrm{~b}$. The transfer function between input $G_{S}(s)$ and the output variable $T_{M}(s)$ which models how a change in steam flow rate affects the milk output temperature is thus obtained as:

$G_{H}=\frac{T_{M 1^{\prime}}(s)}{G_{S}(s)}=\frac{n u m 1}{\operatorname{den} 1}$

where $T_{M l}(s)$ is the system response due to input $G_{S}(s) ; n u m 1=H_{S}$ and $\operatorname{den} 1$ is given by: 


$$
\begin{aligned}
\operatorname{den} 1=C_{S} C_{W} C_{M} & R_{S W} R_{W M} s^{3} \\
& +\left[C_{W} C_{M} R_{W M}+C_{S} C_{M} R_{W M}+G_{M} C_{S} C_{W} C_{P M} R_{S W} R_{W M}+C_{S} C_{W} R_{S W}\right. \\
& \left.+C_{S} C_{M} R_{S W}\right] s^{2} \\
& +\left[G_{M} C_{W} C_{P M} R_{W M}+C_{W}+C_{M}+G_{M} C_{S} C_{P M} R_{W M}+C_{S}\right. \\
& \left.+G_{M} C_{S} C_{P M} R_{S W}+\frac{C_{M} R_{M W}}{R_{S W}}\right] s+G_{M} C_{P M}
\end{aligned}
$$

The transfer function which models how a change in milk inflow temperature (disturbance) affects the output temperature of milk is obtained as:

$$
G_{D}=\frac{T_{M 2^{\prime}}(s)}{T_{M}(s)}=\frac{n u m 2}{\operatorname{den} 2}
$$

where $T_{M 2} \cdot(s)$ is the system response due to disturbance input $T_{M}(s)$; and num 2 and $\operatorname{den} 2$ are given by:

$$
\begin{aligned}
\text { num } 2=G_{M} C_{S} & C_{W} C_{P M} R_{S W} R_{W M} s^{2} \\
& +\left[G_{M} C_{W} C_{P M} R_{W M}+G_{M} C_{S} C_{P M} R_{W M}+G_{M} C_{S} C_{P M} R_{S W}+\frac{C_{M} R_{M W}}{R_{S W}}\right] s \\
& -G_{M} C_{P M} \\
\text { den } 2=C_{S} C_{W} C_{M} R_{S W} R_{W M} s^{3} & +\left[C_{W} C_{M} R_{W M}+C_{S} C_{M} R_{W M}+G_{M} C_{S} C_{W} C_{P M} R_{S W} R_{W M}+C_{S} C_{W} R_{S W}\right. \\
& \left.+C_{S} C_{M} R_{S W}\right] s^{2} \\
& +\left[G_{M} C_{W} C_{P M} R_{W M}+C_{W}+C_{M}+G_{M} C_{S} C_{P M} R_{W M}+C_{S}\right. \\
& \left.+G_{M} C_{S} C_{P M} R_{S W}+\frac{C_{M} R_{M W}}{R_{S W}}\right] s+G_{M} C_{P M}
\end{aligned}
$$

The steam flow rate $G_{S}(s)$ is a function of the control signal $U(\mathrm{~s})$ applied to the steam control valve $G_{v}$ and so the entire open loop system is illustrated in Figure 3.

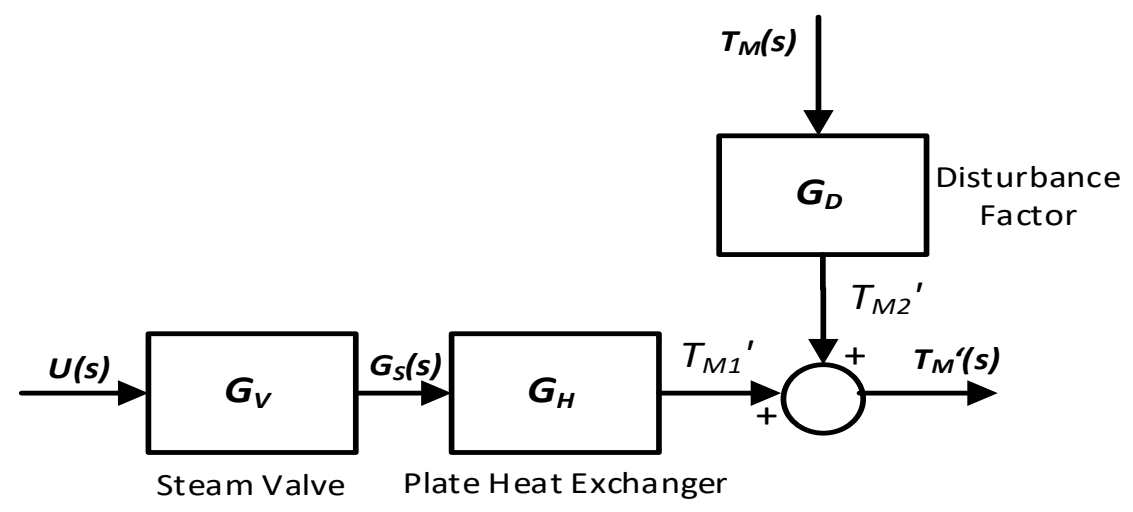

Figure 3. Open Loop Block Diagram of the Process

\section{Methodology}

The open loop system in Figure 3 was simulated in MATLAB environment to obtained the unit step responses of the system due to both the main input $\mathrm{U}(\mathrm{s})$ as well as the disturbance $\mathrm{T}_{\mathrm{M}}(\mathrm{s})$. 
The system parameter values used were obtained from a local processing factory, Fan Milk Nigeria Plc, Ibadan, Nigeria and some standard reference materials, while some were calculated using standard procedures. The parameter values are as shown in Table 2.

Table 2. Milk Pasteurization Process Parameter Values

\begin{tabular}{|l|c|c|}
\hline \multicolumn{1}{|c|}{ Name } & Notation & Value \\
\hline Temperature of steam flow into the PHE & $\mathrm{T}_{\mathrm{S}}$ & $85^{0}$ \\
\hline Steam Flow Rate in the PHE & $\mathrm{G}_{\mathrm{S}}$ & $0.659 \mathrm{~kg} / \mathrm{s}$ \\
\hline Steam Specific Heat Capacity & $\mathrm{C}_{\mathrm{PS}}$ & $1.979 \times 10^{3} \mathrm{~J} / \mathrm{kg} \mathrm{K}$ \\
\hline Latent Heat of Steam & $\mathrm{H}_{\mathrm{S}}$ & $2.29364 \times 10^{6} \mathrm{~J} / \mathrm{kg}$ \\
\hline Steam Convective Resistance & $\mathrm{R}_{\mathrm{S}}$ & $2.373 \times 10^{-5} \mathrm{~K} / \mathrm{W}$ \\
\hline Steam Thermal Capacitance & $\mathrm{C}_{\mathrm{S}}$ & $1304.16 \mathrm{~W} / \mathrm{K}$ \\
\hline PHE Conductive Resistance & $\mathrm{R}_{\mathrm{PHE}}$ & $6.972 \times 10^{-6} \mathrm{~K} / \mathrm{W}$ \\
\hline Milk Convective Resistance & $\mathrm{R}_{\mathrm{M}}$ & $9.091 \times 10^{-5} \mathrm{~K} / \mathrm{W}$ \\
\hline Milk Flow Rate inside PHE & $\mathrm{G}_{\mathrm{M}}$ & $6.94 \mathrm{~kg} / \mathrm{s}$ \\
\hline Pasteurization Temperature Set Point & $\mathrm{T}_{\mathrm{SP}}$ & $75^{0}$ \\
\hline Milk Thermal Capacity & $\mathrm{C}_{\mathrm{M}}$ & $26163.8 \mathrm{~W} / \mathrm{K}$ \\
\hline Milk specific Heat Capacity & $\mathrm{C}_{\mathrm{PM}}$ & $3.77 \times 10^{3} \mathrm{~J} / \mathrm{kg} / \mathrm{K}$ \\
\hline Control Valve Coefficient & $\mathrm{G}_{\mathrm{V}}$ & $1.28 \times 10^{-2} \mathrm{~m} / \mathrm{s}$ \\
\hline PHE Thermal Capacitance & $\mathrm{C}_{\mathrm{W}}$ & $460 \mathrm{~J} / \mathrm{kgK}$ \\
\hline
\end{tabular}

With these parameter values, the following system transfer functions were obtained:

$$
\begin{aligned}
& G_{P}=G_{V} G_{H}=\frac{2.936 \times 10^{4}}{40.33 s^{3}+5342 s^{2}+1.24 \times 10^{5} s+2.616 \times 10^{4}} \\
& G_{D}=\frac{40.33 s^{2}+9.603 \times 10^{4} s+2.616 \times 10^{4}}{40.33 s^{3}+5342 s^{2}+1.24 \times 10^{5} s+2.616 \times 10^{4}}
\end{aligned}
$$

PID Controller $G_{C}$ and a unit feedback $H$ were added to the system in Figure 3 in order to apply the PID object controllers in the forms of Proportional (P), Proportional plus Integral (PI), Proportional plus Derivative (PD) and Proportional Plus Integral plus Derivative (PID) to the modelled plant as shown in Figure 4. This is to improve the system performance [13]. The new system was again simulated in MATLAB environment to obtain the unit step responses. The command pidtune was used to optimize the selected PID controller. Given a plant model, pidtune automatically tunes the PID gains to balance performance (response time) and robustness (stability margins).

In order to achieve a pre-emptive control action that the PID feedback controller cannot achieve, a feedforward controller was added to the feedback control system. The feedforward controller transfer function GF is obtained by making the output variable equal to zero with the disturbance input applied to the plant as shown in Figure 5 [14].

The appropriate feedforward controller for the system is obtained as:

$G_{F}-\frac{G_{D}}{G_{P}}=\frac{-40.33 s^{2}-9.603 \times 10^{4} s-2.616 \times 10^{4}}{2.936 \times 10^{4}}$

The resulting system comprising both the feedback and feedforward controllers is shown in Figure 6:

Simulations were carried out using the combination of feedforward controller and each form of PID controllers. 


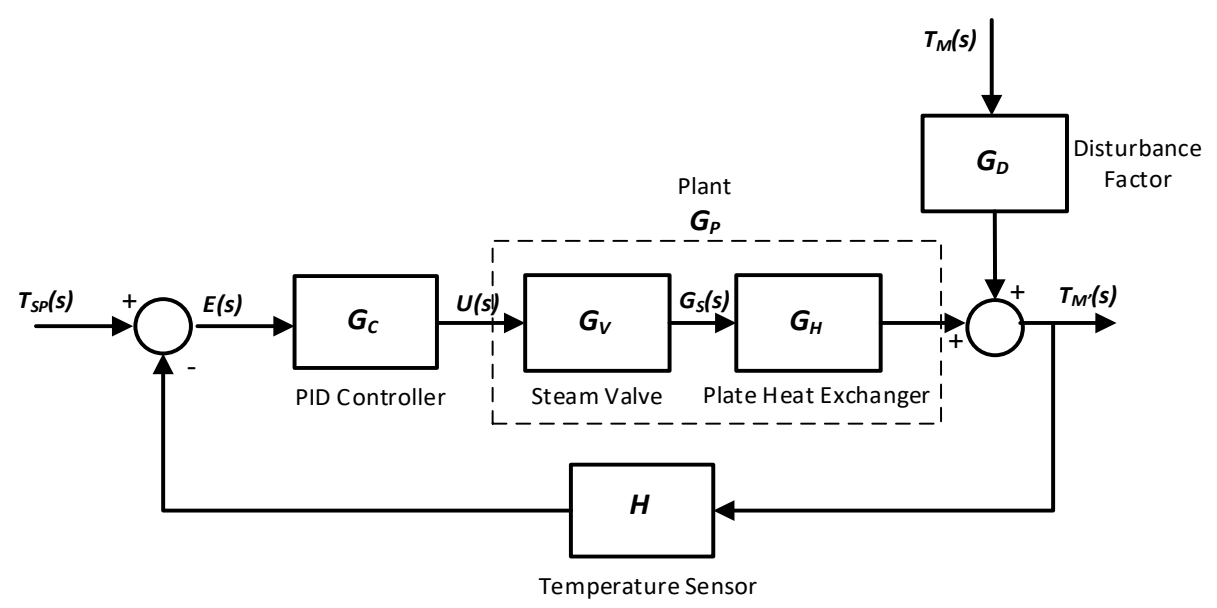

Figure 4. Closed Loop Block Diagram of the Process with PID Controller

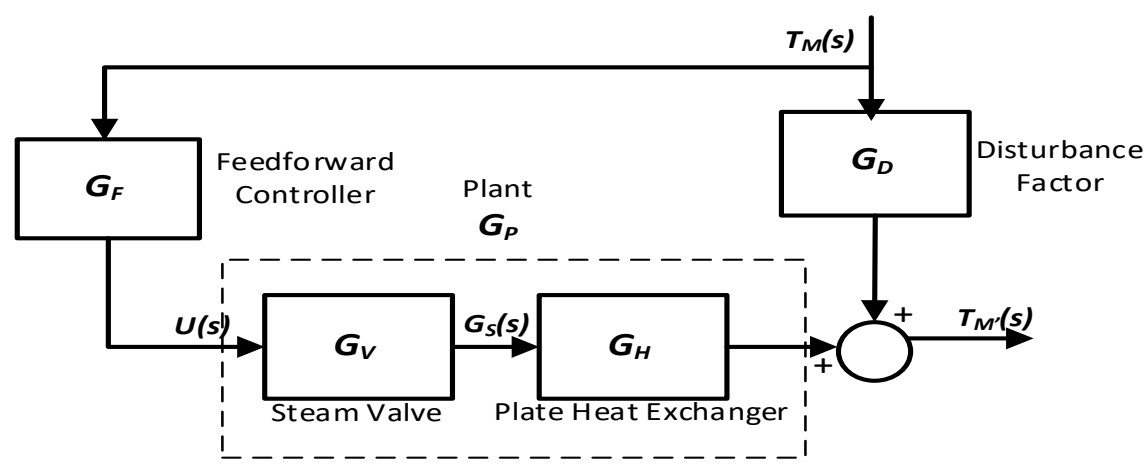

Figure 5. Block Diagram Showing the Connection of the Feedforward Controller

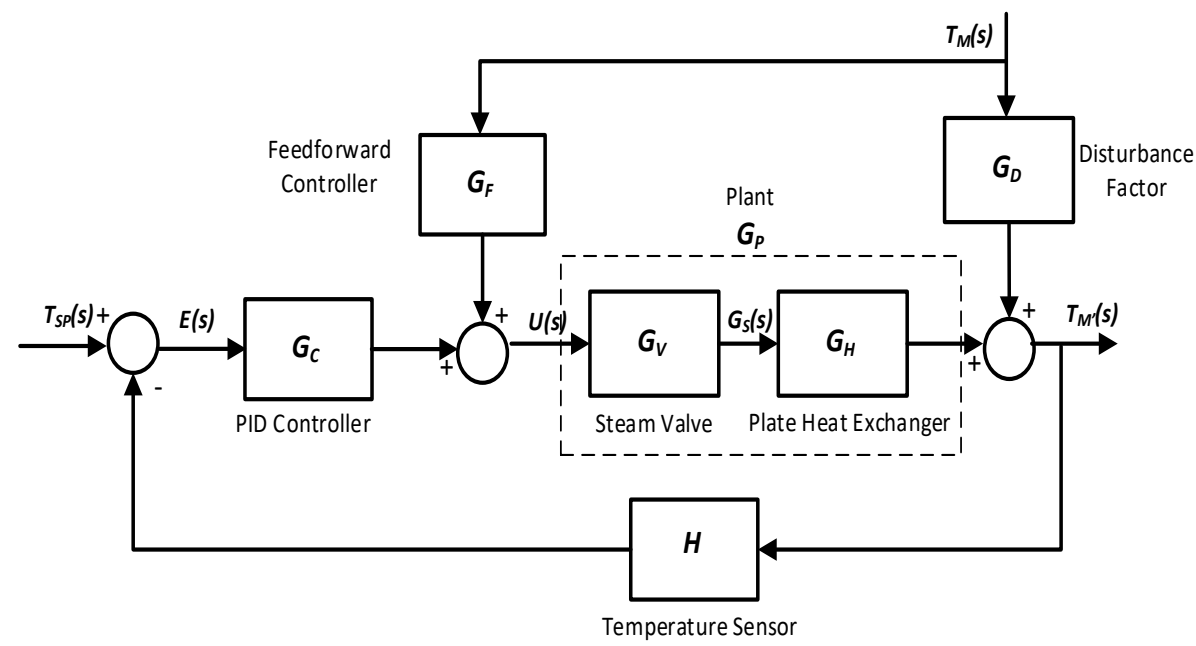

Figure 6. Process Block Diagram with Feedforward and Feedback Controllers 


\section{Simulation Results and Discussions}

The system unit step responses due to the set point input and disturbance input resulting from the simulations carried out with different controllers are illustrated in Figures 7 to 15. The time response parameters for different controllers with respect to the control input and disturbance input are shown in Tables 3 and 4. Open loop controller has a 0\% overshoot but the highest rise time and settling time of $10.3143 \%$ and 18.4089 seconds respectively while its maximum response to unit disturbance stands at 1.1221 at 49.5067 seconds. Feedforward plus PD controller produces the lowest rise time and settling time of 0.0769 second and 0.2453 seconds respectively, the least maximum response to unit disturbance of $1.61 \times 10^{-16}$ at 0.1167 seconds but has an overshoot of $9.2661 \%$. The combination of feedforward and PID controllers produce lower percentage overshoot of $6.2713 \%$ but it is not as fast as it has rise and settling times of 3.7242 and 13.5523 seconds respectively.

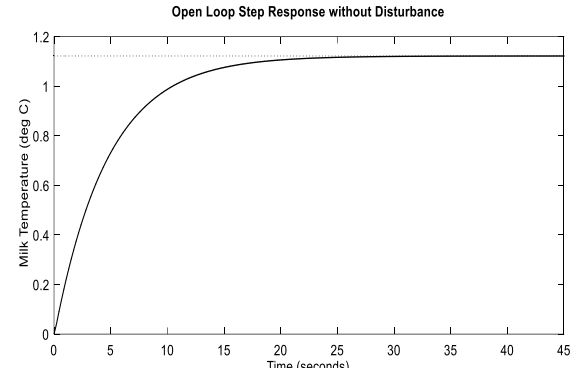

(a)

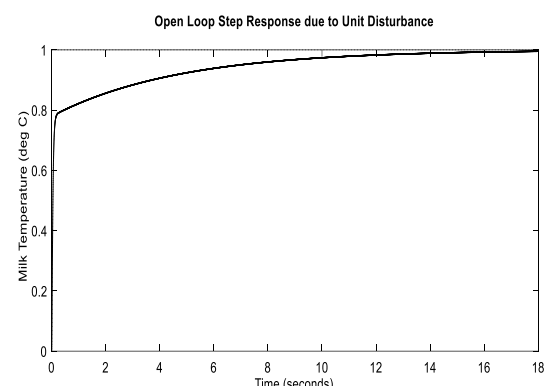

(b)

Figure 7. Open Loop System Unit Step Response (a)Main Input (b)Disturbance Input

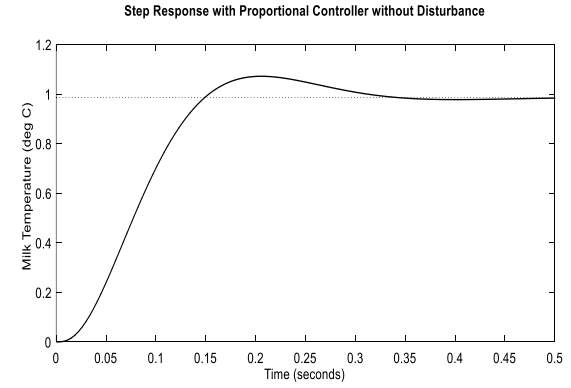

(a)

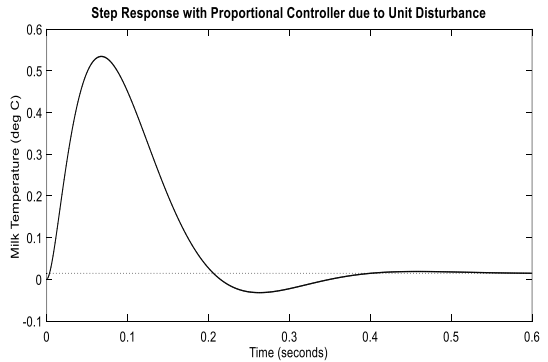

(b)

Figure 8. System Unit Step Response with P Controller (a)Main Input (b)Disturbance Input

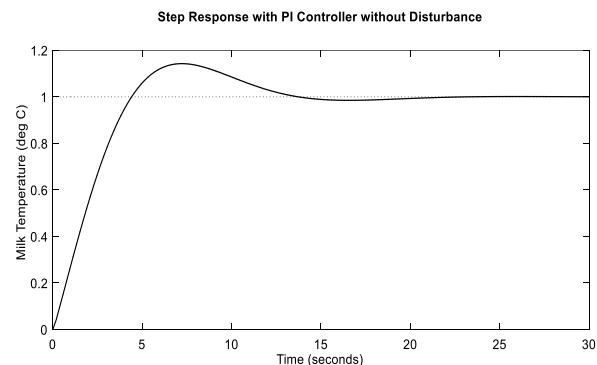

(a)

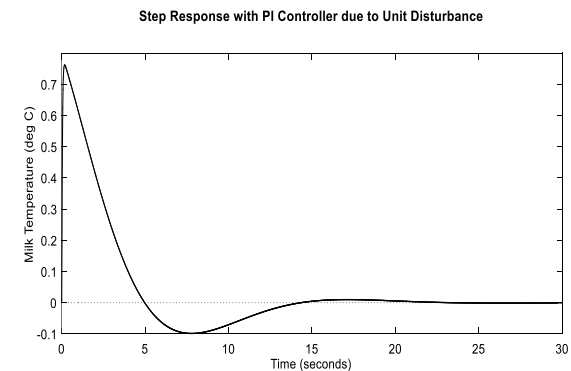

(b)

Figure 9. System Unit Step Response with PI Controller (a)Main Input (b)Disturbance Input 


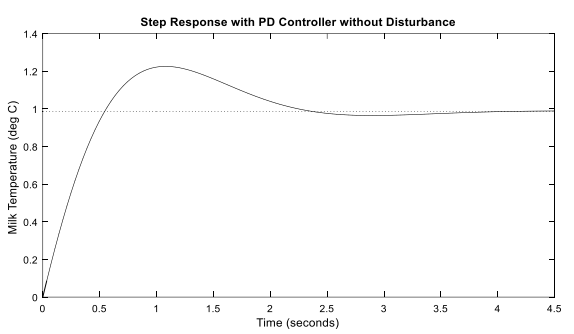

(a)

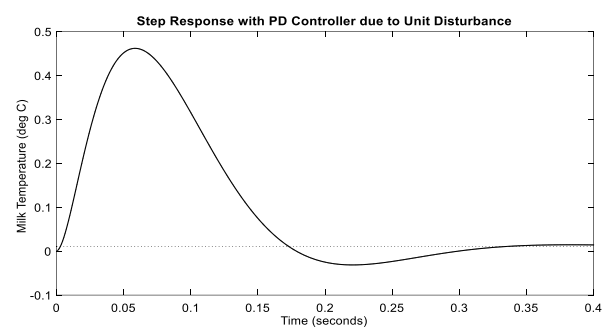

(b)

Figure 10. System Unit Step Response with PD Controller (a)Main Input (b)Disturbance Input

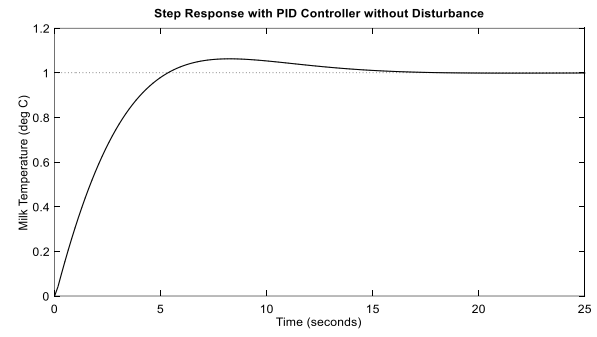

(a)

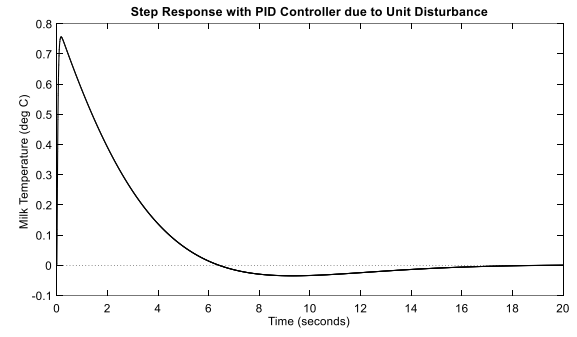

(b)

Figure 11. System Unit Step Response with PID Controller (a)Main Input (b)Disturbance Input

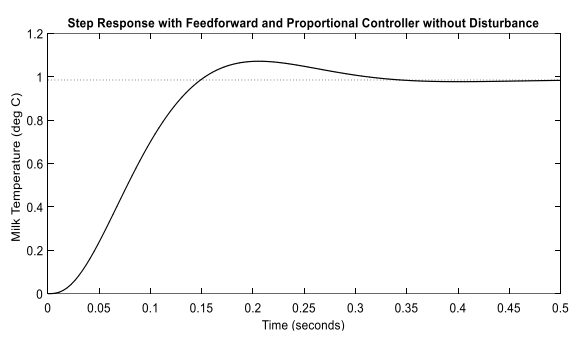

(a)

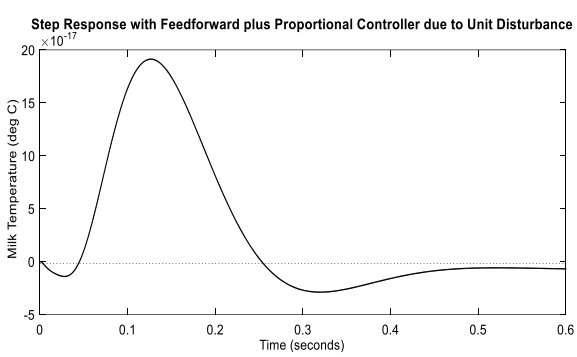

(b)

Figure 12. System Unit Step Response with Feedforward plus P Controller (a)Main Input (b)Disturbance Input

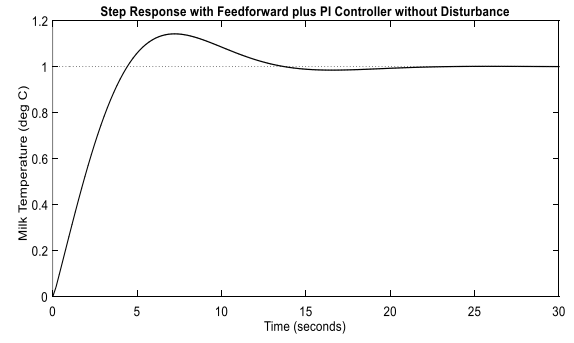

(a)

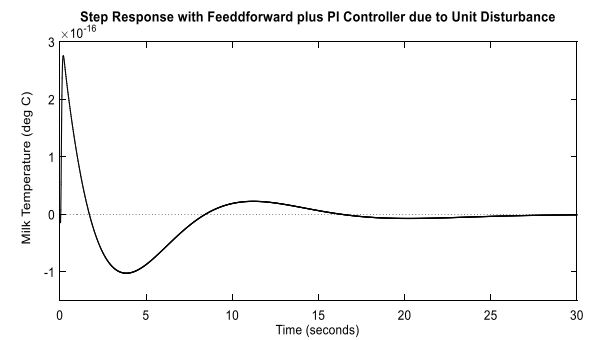

(b)

Figure 13. System Unit Step Response with Feedforward Plus PI Controller (a)Main Input (b)Disturbance Input 


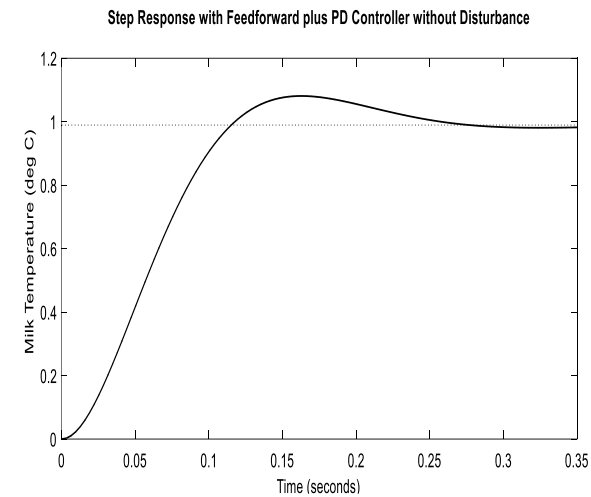

(a)

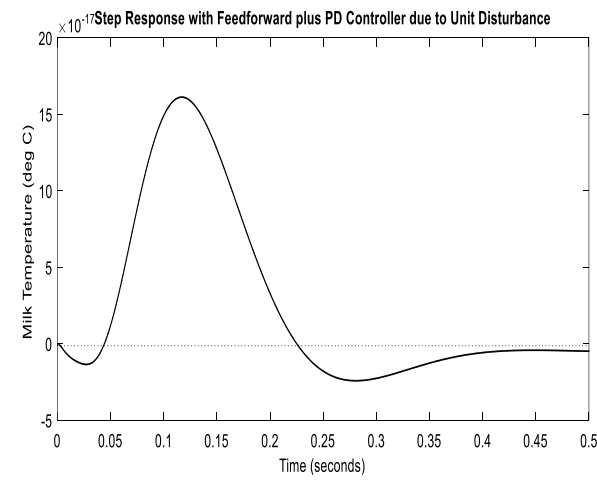

(b)

Figure 14. System Unit Step Response with Feedforward plus PD Controller (a)Main Input (b)Disturbance Input

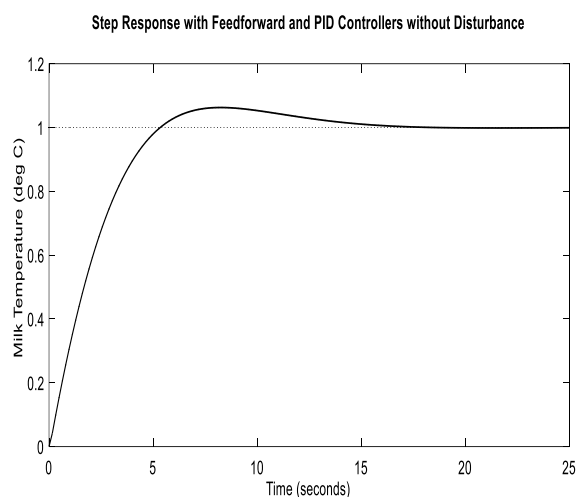

(a)

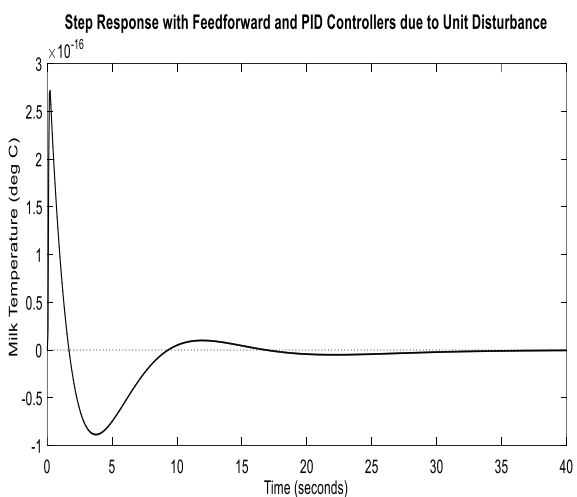

(b)

Figure 15. System Unit Step Response with Feedforward plus PID Controller (a)Main Input (b)Disturbance Input

Table 3. Time Response Parameters for Different Controllers with Respect to the Control Input

\begin{tabular}{|c|c|c|c|c|c|c|c|}
\hline $\begin{array}{c}\text { Controller } \\
\text { type }\end{array}$ & $\begin{array}{c}\text { Rise } \\
\text { time }\end{array}$ & $\begin{array}{c}\text { Settling } \\
\text { time }\end{array}$ & $\begin{array}{c}\text { Settling } \\
\text { min }\end{array}$ & $\begin{array}{c}\text { Settling } \\
\max \end{array}$ & $\begin{array}{c}\% \\
\text { Overshoot }\end{array}$ & Peak & $\begin{array}{c}\text { Peak } \\
\text { time }\end{array}$ \\
\hline Open loop & 10.3143 & 18.4089 & 1.0139 & 1.1221 & 0 & 1.1221 & 49.507 \\
\hline $\begin{array}{c}\text { P } \\
\text { Controller }\end{array}$ & 0.0947 & 0.3037 & 0.9052 & 1.0718 & 8.7684 & 1.0718 & 0.205 \\
\hline $\begin{array}{c}\text { PI } \\
\text { Controller }\end{array}$ & 3.2907 & 12.4994 & 0.9173 & 1.143 & 14.295 & 1.143 & 7.2144 \\
\hline $\begin{array}{c}\text { PD } \\
\text { Controller }\end{array}$ & 0.0769 & 0.2453 & 0.9089 & 1.081 & 9.2661 & 1.081 & 0.1633 \\
\hline $\begin{array}{c}\text { PID } \\
\text { Controller }\end{array}$ & 3.7242 & 13.5523 & 0.9107 & 1.0627 & 6.2713 & 1.0627 & 8.3074 \\
\hline $\begin{array}{c}\text { Feedforward } \\
+P\end{array}$ & 0.0947 & 0.3037 & 0.9052 & 1.0718 & 8.7684 & 1.0718 & 0.205 \\
\hline $\begin{array}{c}\text { Feedforward } \\
\text { plus PI }\end{array}$ & 3.2907 & 12.4994 & 0.9173 & 1.143 & 14.295 & 1.143 & 7.2144 \\
\hline $\begin{array}{c}\text { Feedforward } \\
\text { plusPD }\end{array}$ & 0.0769 & 0.2453 & 0.9089 & 1.081 & 9.2661 & 1.081 & 0.1633 \\
\hline $\begin{array}{c}\text { Feedforward } \\
\text { plus PID }\end{array}$ & 3.7242 & 13.5523 & 0.9107 & 1.0627 & 6.2713 & 1.0627 & 6.2713 \\
\hline
\end{tabular}


Table 4. Time Response Parameters for Different Controllers with Respect to the Disturbance Input

\begin{tabular}{|c|c|c|c|c|c|c|c|}
\hline $\begin{array}{c}\text { Controller } \\
\text { type }\end{array}$ & $\begin{array}{c}\text { Rise } \\
\text { time }\end{array}$ & $\begin{array}{c}\text { Settling } \\
\text { time }\end{array}$ & $\begin{array}{c}\text { Settling } \\
\text { min }\end{array}$ & $\begin{array}{c}\text { Settling } \\
\text { max }\end{array}$ & $\begin{array}{c}\% \\
\text { Overshoot }\end{array}$ & Peak & $\begin{array}{c}\text { Peak } \\
\text { time }\end{array}$ \\
\hline Open loop & 3.6951 & 11.2618 & 0.9 & 0.9966 & 0 & 0 & 19.531 \\
\hline $\begin{array}{c}\text { P } \\
\text { Controller }\end{array}$ & 0.0024 & 0.3615 & -0.032 & 0.5344 & $3.6 \times 10^{3}$ & 217.70 & 0.0675 \\
\hline $\begin{array}{c}\text { PI } \\
\text { Controller }\end{array}$ & 0 & 12.9604 & -0.098 & 0.762 & Inf & Inf & 0.1785 \\
\hline $\begin{array}{c}\text { PD } \\
\text { Controller }\end{array}$ & 0.0021 & 0.3032 & -0.031 & 0.4618 & $4.3 \times 10^{3}$ & 294.85 & 0.0589 \\
\hline $\begin{array}{c}\text { PID } \\
\text { Controller }\end{array}$ & 0 & 13.7461 & -0.035 & 0.7563 & Inf & Inf & 0.1686 \\
\hline $\begin{array}{c}\text { Feedforward } \\
\text { plus P }\end{array}$ & 0.0023 & $\mathrm{NaN}$ & $-2.9 \times 10^{-17}$ & $1.9 \times 10^{-16}$ & $1.5 \times 10^{3}$ & $1.1 \times 10^{4}$ & 0.1265 \\
\hline $\begin{array}{c}\text { Feedforward } \\
\text { plus PI }\end{array}$ & 0 & 22.9791 & $-1.0 \times 10^{-16}$ & $2.8 \times 10^{-16}$ & Inf & Inf & 0.1913 \\
\hline $\begin{array}{c}\text { Feedforward } \\
\text { plus PD }\end{array}$ & 0.002 & $\mathrm{NaN}$ & $-2.4 \times 10^{-17}$ & $1.6 \times 10^{-16}$ & $1.8 \times 10^{3}$ & $1.3 \times 10^{3}$ & 0.1167 \\
\hline $\begin{array}{c}\text { Feedforward } \\
\text { plus PID }\end{array}$ & 0 & 14.6366 & $-8.9 \times 10^{-17}$ & $2.2 \times 10^{-16}$ & Inf & Inf & 0.2162 \\
\hline
\end{tabular}

The results show that the addition of the feedforward controller has greatly improved the system's disturbance rejection. However, the combination of the feedforward controller and PD has the greatest effect on disturbance rejection.

Feedforward plus PD produces the fastest response but its stability margin is not as high as that of Feedforward plus PID due to its relatively higher overshoot.

\section{Conclusion}

The model that fully describes the relationship between the steam flow rate and the milk temperature in the heat exchanger has been developed. Different types of PID controllers and a feedforward controller have been designed to achieve adequate pasteurization of milk with a view to realizing high response speed and margin of stability as well as good disturbance rejection. In all, a combination of Feedforward and PD controllers maintains a balance between speed of response, stability margin and disturbance rejection. This combination seems to provide the most appropriate condition for milk pasteurization and is therefore recommended as the most suitable controller for the process under study. The choice of controller may however be improved upon by adopting more recent controller design techniques.

\section{Acknowledgments}

The author wishes to acknowledge the contribution of Seun Topa Ojo to the success of this work.

\section{References}

[1] I. Shaw, "Pasteurization of Dairy Products: Times, Temperatures and Evidence for Control of Pathogens", Client Report FW0374, Institute of Environmental Science \& Research Limited, New Zealand, (2003).

[2] H. D. Kay, J. R. Cuttell, A. R. Mattick and A. Rowland, "Milk Pasteurization Planning, Plant, Operation and Control", World Health Monograph Series No. 14, (1953).

[3] S. P. Oliver, B. M. Jayarao and R. A. Almeida, "Foodborne Pathogens and Disease", Foodborne Pathogens and Disease, vol. 2, no. 2, (2005), pp. 115-129. 
[4] C. F. Alastruey, M. De la Sen and M. Garcia-Sanz, "Modelling and Identification of a High Temperature Short Time Pasteurization Process Including Delays", 7th Mediterranean Conference on Control and Automation, Haifo, Israel, (1999) June 28-30.

[5] P. W. Smith, "Milk Pasteurization", Fact Sheet No 57, United States Department of Agriculture Research Service, Washington D.C., (1981).

[6] S. Sheel and O. Gupta, "High Performance Fuzzy Adaptive PID Speed Control of a Converter Driven DC Motor", Int. Journal of Control and Automation, vol. 5, no. 1, (2012), pp. 71-88.

[7] A. M. Monsorabad, M. T. H. Beheshti and M. Simab, "A Hybrid PSO_Fuzzy_PID Controller for Gas Turbine Speed Control", Int. Journal of Control and Automation, vol. 6, no. 1, (2013), pp. 13-24.

[8] C. Long and N. Sayma, "Heat Transfer", Ventus Publishing ApS, (2009).

[9] T. H. Gebrehiwot, "Heat Transfer in Plate Heat Exchangers", Chemical \& Process Engineering, Faculty of Technology, Lappeenranta University of Technology, (2009).

[10] D. P. Hawn, "Development of a Dynamic Model of a Counterflow Compact Heat Exchanger for Simulation of the Gt-Mhr Recuperator using Matlab and Simulink", M. Sc Thesis, Nuclear Engineering Department, Ohio State University, (2009).

[11] P. Kapustenko, O. Dobromyslova, O. Dobromyslov, O. Perevertaylenko, O. Arsenyeva, O. Ilyunin and E. Shabanov, "Control of Plate Heat Exchanger Outlet Temperature Using Butterfly Valve and Parametric Model Predictive Control Technique", Chemical Engineering Transactions, vol. 18, (2009), pp. 827-832.

[12] E. Cheever, "Thermal Systems", Department of Engineering, Swarthmore College, (2012).

[13] A. H. Al_Tae and S. A. Al-Naimi, "Comparative Study of Temperature Control in a Heat Exchanger Process", Eng. \& Tech Journal, vol. 30, no. 10, (2012), pp. 1707-1731.

[14] T. E. Marlin, "Process Control: Designing Processes and Control Systems for Dynamic Performance", 2nd ed., McGraw Hill Chemical Engineering Series, (2015).

\section{Author}

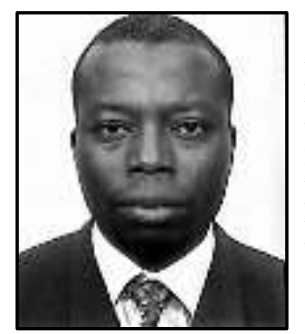

Ismaila Adeniyi Kamil obtained a B.Sc. Degree in Electronic \& Electrical Engineering from Obafemi Awolowo University, Ile-Ife, Nigeria in 1989, M.Phil. Degree in Electrical Engineering from University of Lagos, Nigeria in 1997 and a Ph.D. in Electrical Engineering from University of Ibadan, Nigeria in 2010.He is currently a Senior Lecturer in the Department of Electrical and Electronic Engineering, University of Ibadan, Nigeria. His areas of interest include Signal Processing, Wireless Communication and Control \& Instrumentation. 
International Journal of Control and Automation

Vol. 11, No. 8 (2018) 